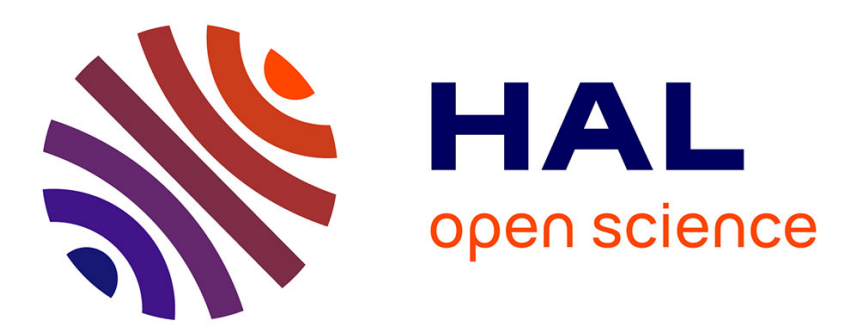

\title{
Psoriasis and metabolic and cardiovascular comorbidities in children: A systematic review
}

\author{
A. Badaoui, P. Tounian, E. Mahé
}

\section{To cite this version:}

A. Badaoui, P. Tounian, E. Mahé. Psoriasis and metabolic and cardiovascular comorbidities in children: A systematic review. Archives de Pédiatrie, 2019, 26 (2), pp.86-94. 10.1016/j.arcped.2018.12.005 . hal-02339753

\section{HAL Id: hal-02339753 \\ https://hal.sorbonne-universite.fr/hal-02339753}

Submitted on 30 Oct 2019

HAL is a multi-disciplinary open access archive for the deposit and dissemination of scientific research documents, whether they are published or not. The documents may come from teaching and research institutions in France or abroad, or from public or private research centers.
L'archive ouverte pluridisciplinaire $\mathbf{H A L}$, est destinée au dépôt et à la diffusion de documents scientifiques de niveau recherche, publiés ou non, émanant des établissements d'enseignement et de recherche français ou étrangers, des laboratoires publics ou privés. 
archives-ouvertes

\title{
Psoriasis and metabolic and cardiovascular comorbidities in children: A systematic review
}

\author{
A. Badaoui, P. Tounian, E. Mahé
}

\section{To cite this version:}

A. Badaoui, P. Tounian, E. Mahé. Psoriasis and metabolic and cardiovascular comorbidities in children: A systematic review. Archives de Pédiatrie, Elsevier, 2019, 26 (2), pp.86-94. 10.1016/j.arcped.2018.12.005 . hal-02339753

HAL Id: hal-02339753

\section{https: / hal.sorbonne-universite.fr/hal-02339753}

Submitted on 30 Oct 2019

HAL is a multi-disciplinary open access archive for the deposit and dissemination of scientific research documents, whether they are published or not. The documents may come from teaching and research institutions in France or abroad, or from public or private research centers.
L'archive ouverte pluridisciplinaire HAL, est destinée au dépôt et à la diffusion de documents scientifiques de niveau recherche, publiés ou non, émanant des établissements d'enseignement et de recherche français ou étrangers, des laboratoires publics ou privés. 


\title{
Psoriasis and metabolic and cardiovascular comorbidities in children: A systematic review
}

\author{
A. Badaoui ${ }^{\text {a }}$, P. Tounian ${ }^{\text {b }}$, E. Mahé ${ }^{\mathrm{a}, *}$ \\ a Service de Dermatologie, Centre Hospitalier Victor-Dupouy, 69, rue du Lieutenant-Colonel-Prud'hon, 95100 Argenteuil, France \\ ${ }^{\mathrm{b}}$ Service de nutrition et gastro-entérologie pédiatriques, Hôpital Trousseau, Assistance publique-Hôpitaux de Paris, Université Pierre-et-Marie-Curie, Paris VI, \\ 75012 Paris, France
}

A R T I C L E I N F O

\section{Article history:}

Received 24 August 2018

Accepted 11 December 2018

Available online $\mathrm{xxx}$

\section{Keywords:}

Psoriasis

Childhood

Children

Obesity

Diabetes

Cardiovascular risk factors

Metabolic syndrome

Body mass index

Comorbidity

\begin{abstract}
A B S T R A C T
Introduction: Psoriasis is associated with a higher risk of cardiovascular and/or metabolic comorbidity in adults, but discordant data have been reported in children.

Objective: To evaluate the frequency of metabolic and cardiovascular comorbidity in children with psoriasis and to establish whether age at onset of psoriasis correlates with metabolic and cardiovascular comorbidity in adulthood.

Material and methods: We conducted a systematic review on MEDLINE, using PubMed and Ovid. The search was limited to children ( $<18$ years). The following key words were used: "psoriasis" with "children or childhood or adolescent" and "obesity" or "hypertension" or "diabetes" or "dyslipidemia" or "cardiovascular risk factor" or "myocardial infarction" or "stroke" or "coronaropathy" or "comorbidity". The reference lists of the articles retrieved were checked for additional relevant studies.

Results: A total of 377 potential citations were analyzed. After removing duplicate articles and reviewing eligibility in titles and abstracts, 16 articles remained. The studies analyzed revealed significantly higher risk of overweight and obesity in children with psoriasis, despite the numerous definitions used. Four studies reported higher risk of abdominal obesity in children with psoriasis. Data on hypertension, diabetes, dyslipidemia, metabolic syndrome, and major cardiovascular events suggested there was no higher risk of these comorbidities in children with psoriasis. Two studies suggested that age at onset of psoriasis did not increase the frequency of comorbidity in adulthood.

Conclusion: This systematic review suggests that psoriasis in children is not associated with metabolic and cardiovascular comorbidities, except overweight and obesity, for which higher prevalence is clearly demonstrated in the literature.
\end{abstract}

\section{Introduction}

Psoriasis affects $2-3 \%$ of the general population in Western countries, and $0.7-1.2 \%$ of children [1,2]. Its pathophysiology involves multiple mechanisms, including genetic predisposition, immune mechanisms, and exogenous trigger factors such as stress, drugs, and infection.

Psoriasis in adults is associated with cardiovascular and metabolic comorbidity, particularly diabetes, hypertension, dyslipidemia, and major adverse cardiovascular events (MACEs).

\footnotetext{
* Corresponding author.

E-mail address: E.Mahé ${ }^{\mathrm{a}_{*}}$ emmanuel.mahe@ch-argenteuil.fr (E. Mahé).
}

The exact link between these diseases is still debated and not fully understood [3]. Some authors have suggested the concept of "psoriatic march" according to which severe psoriasis may lead to cardiovascular comorbidity, probably through systemic inflammation and insulin resistance, causing endothelial dysfunction, then atherosclerosis, and finally myocardial infarction or stroke [4]. Some studies report that obesity may also induce onset of psoriasis through synthesis of inflammatory adipokines [5-10].

Recently, several studies have reported a link between childhood psoriasis and cardiovascular and metabolic comorbidity, with discordant results. Some authors suggest that all children with psoriasis should be screened for cardiovascular and metabolic comorbidities and propose guidelines [2,11-15]. 
We conducted a systematic review to evaluate the frequency of metabolic and cardiovascular comorbidity in children with psoriasis and to determine whether age at onset of the disease correlates with these comorbidities in adulthood.

\section{Material and methods}

\subsection{Search strategy and selection of articles}

Bibliographic searches were conducted in December 2016 on MEDLINE, using PubMed (http://www.ncbi.nlm.nih.gov/sites/ entrez) and Ovid (http://www.ovid.com) as interfaces. No language or date restrictions were applied. The search was limited to children ( $<18$ years). The search used the following keywords: "psoriasis" in combination with "children" or "childhood or adolescent" and: "obesity" or "hypertension" or "diabetes" or "dyslipidemia" or "cardiovascular risk factor" or "myocardial infarction" or "stroke" or "coronaropathy" or "comorbidity." The reference lists of the articles thus retrieved were checked for additional relevant studies. Each article selected was then analyzed on Google Scholar (https://scholar.google.fr/) in search of articles in which it was cited.

The primary inclusion criteria were developed for initial selection of relevant articles, i. e., studies analyzing the relationship between psoriasis and comorbidities. Two of the authors (A. B. and E. M.) screened titles and abstracts to evaluate this initial relevance. If relevance was unclear, studies were included and subsequently reviewed in greater detail. The two authors performed the search independently according to the Newcastle-Ottawa Scale for assessing the quality of nonrandomized studies in a meta-analysis.

We then selected cohort and cross-sectional studies published as original articles or as letters if sufficient information was available. Answers to editors were also included when they contained information that was useful to complete the results of an original article. Case reports, reviews, commentaries, editorials, and letters to the authors were not considered eligible. All studies had to be independent, to avoid giving double weight, and had to provide sufficient data concerning their results.

Titles, abstracts, and full-text articles were screened by two authors (A.B. and E.M.), who extracted data using a structured form.

\subsection{Data extraction}

A data extraction form was developed to collect information:

- general data: year of publication, study design, main focus of study, location, mean age of study population, and number of children included;

- psoriasis information: definition and type of psoriasis; age at onset; psoriasis arthritis;

- control groups: healthy or not, rules for matching (age, gender, location);

- comorbidity evaluation and definition: for each comorbidity;

- statistical information: statistical methods, adjustment for confounding variables (age, gender, location).

Two reviewers (A.B., E.M) independently extracted data from each article, and the two sets of results were compared for concordance and re-reviewed if necessary. Inconsistencies were reviewed until agreement was reached.

The data are summarized in Table 1 . The details of each comorbidity are summarized in other tables.

\subsection{Statistics}

The original aim of the study was to perform a meta-analysis of the results, but this was made impossible by the many different definitions and outcome measures used in the articles.

\section{Results}

The search strategy yielded 377 potential articles. After removing duplicates and reviewing eligibility in titles and abstracts, 16 articles remained (Fig. 1) [2,11-14,16-28]: eight retrospective case-control studies, four retrospective national registry studies, one retrospective study based on a questionnaire sent to patients, two cross-sectional studies, and one retrospective cohort study. Four studies were from the United States, two each from Germany, France, and Denmark, one each from the Netherlands, Italy, China, Australia, and Portugal, and one international study (Table 1 ).

Data on age and gender are detailed in Table 1. Overall, 11,787 psoriasis patients (7660 children, 4127 adults) were analyzed. Thirteen studies provided sex ratios: among the 2187 children with gender information, 1119 (51.2\%) were male and 1068 (48.8\%) female; and among the 4127 adults, 2169 (52.6\%) were male, and 1958 (47.4\%) female.

Psoriasis was diagnosed by a dermatologist in 12 studies (75.0\%), and declared by the patients in one $(6.2 \%)$. In the other three studies (18.7\%), patients were included from a database using the International Statistical Classification of Diseases and Related Health (ICD, 8th to 10th revision).

The study objectives comprised assessment of the frequency of comorbidities in children with psoriasis in ten studies (62.5\%), the impact of childhood onset of psoriasis on comorbidity frequency in adulthood in two (12.5\%), the relationship between adiposity and severity of psoriasis in one (6.2\%), the temporal association between psoriasis and adiposity in one (6.2\%), lipoprotein composition in psoriatic patients in one $(6.2 \%)$, and prediction of severe psoriasis by risk factors for adult obesity in one $(6.2 \%)$ (Table 1).

\subsection{Overweight and obesity}

Thirteen studies provided data on overweight and obesity. Overweight was defined in eight studies, obesity in nine, and abdominal obesity in two. Definitions differed, making the results difficult to analyze on common criteria. The definitions comprised body-mass index (BMI: $>85$ th or $>95$ th percentile; $n=5$ ), International Obesity Task Force criteria (IOTF: $n=2$ ), waist circumference (WC: $n=3$ ), waist-to-height ratio (WtHR: $n=3$ ), or ICD code $(n=2)$ (Table 2). Two studies compared mean BMI, WC, or WtHR values.

Six studies (studies $1,5-7,11,14$ ) reported a higher risk of overweight in children with psoriasis, six (studies 5-7, 11, 14, 16) a higher risk of obesity, four (studies $7,11,14,15$ ) a higher risk of abdominal obesity, and two (studies 2,13) a higher risk of obesity using ICD-10 code E66. Two studies (studies 15,16 ) reported no difference in overweight, one (study 15) no difference in obesity, and one (study 9) no difference in WC. Six studies (studies 4, 7, 9, $11,12,16)$ reported higher BMI but below the threshold for overweight or obesity and three (studies $11,12,16$ ) a higher mean WC without analysis in terms of age or gender.

Two studies (studies 5, 6) reported a stronger association between overweight/obesity and disease severity, three (studies $7,14,15$ ) no difference, and one no correlation with severity except in the moderate-to-severe psoriasis group, which showed a higher WtHR. 


\begin{tabular}{|c|c|c|c|c|c|c|c|}
\hline No. & Study & Type of study & Age (years) & $\begin{array}{l}\text { Cases (gender)/controls } \\
\text { (gender) }\end{array}$ & Diagnosis of psoriasis & Aim of study & Comorbidities analyzed \\
\hline 1 & Boccardi 2009 Italy [16] & Case-control & $<15$ & $96(52 \mathrm{M} / 44 \mathrm{~F}) / 100(43 \mathrm{M} / 57 \mathrm{~F})$ & Dermatologists & Frequency of overweight & Overweight and obesity \\
\hline 2 & Augustin 2010 Germany [2] & National registry (GEK 2005) & $<20$ & $2549(\mathrm{NR}) / 331,758(\mathrm{NR})$ & ICD-10 Code $\left(\mathrm{L} 40^{\mathrm{a}}\right)$ & Frequency of comorbidities & $\begin{array}{l}\text { Overweight and obesity, } \\
\text { dyslipidemia, diabetes, } \\
\text { hypertension, MACEs }\end{array}$ \\
\hline 3 & De Jager 2010 Netherlands [17] & Retrospective on questionnaire & Adults & $1926(929 \mathrm{M} / 997 \mathrm{~F}) / \mathrm{NA}$ & $\begin{array}{l}\text { Patients, members of the Dutch } \\
\text { Psoriasis Society }\end{array}$ & $\begin{array}{l}\text { Epidemiology and clinical } \\
\text { features of psoriasis of } \\
\text { childhood }(<18 \text { years }) \text { and } \\
\text { adult onset }\end{array}$ & $\begin{array}{l}\text { Link between BMI in adulthood } \\
\text { and age at onset of psoriasis }\end{array}$ \\
\hline 4 & Bryld 2010 Denmark [18] & $\begin{array}{l}\text { Retrospective on cohort } \\
\text { (Copenhagen School Health } \\
\text { Records Register) }\end{array}$ & $7-13$ at inclusion & $\begin{array}{l}1074(593 \mathrm{M} / 481 \mathrm{~F}) / 300,384 \\
(152,051 \mathrm{M} / 148,333 \mathrm{~F})\end{array}$ & $\begin{array}{l}\text { ICD-8 code (696.19) or ICD-10 } \\
\text { code (L40.0-L40.9) for } \\
\text { hospitalized patients }\end{array}$ & $\begin{array}{l}\text { Whether severe psoriasis could } \\
\text { be predicted by risk factors for } \\
\text { adult obesity }\end{array}$ & $\begin{array}{l}\text { Overweight and obesity. Link } \\
\text { between obesity and hospital } \\
\text { admission for psoriasis in } \\
\text { adulthood }\end{array}$ \\
\hline 5 & Koebnick 2011 USA [12] & $\begin{array}{l}\text { Californian registry (KPSC } \\
\text { Children's Health Study) }\end{array}$ & $2-<20$ & 1350 (NR)/710,949 (NR) & $\begin{array}{l}\text { ICD-9 code }\left(696.0,696.1^{\mathrm{a}}\right) \text {, } \\
\text { confirmed by a dermatologist }\end{array}$ & $\begin{array}{l}\text { Frequency of obesity and } \\
\text { cardiovascular risk factors }\end{array}$ & $\begin{array}{l}\text { Overweight and obesity, } \\
\text { dyslipidemia }\end{array}$ \\
\hline 6 & Zhu 2012 China [19] & Case-control & $<15$ & $\begin{array}{l}332(174 \mathrm{M} / 158 \mathrm{~F}) / 146(70 \mathrm{M} / \\
76 \mathrm{~F})\end{array}$ & Dermatologists & $\begin{array}{l}\text { Frequency of overweight and } \\
\text { obesity }\end{array}$ & Overweight and obesity \\
\hline 7 & Paller 2012 International [14] & Multicenter, cross-sectional & $5-<18$ & $\begin{array}{l}409(178 \mathrm{M} / 231 \mathrm{~F}) / 205(96 \mathrm{M} / \\
109 \mathrm{~F})\end{array}$ & Dermatologists & $\begin{array}{l}\text { Relationship between adiposity } \\
\text { and severity of psoriasis }\end{array}$ & $\begin{array}{l}\text { Overweight and obesity, } \\
\text { hypertension, MACEs }\end{array}$ \\
\hline 8 & Mahé 2013 France [20] & Multicenter, cross-sectional & Adults & $2201(1240 \mathrm{M} / 961 \mathrm{~F}) / \mathrm{NA}$ & Dermatologists & $\begin{array}{l}\text { Relationship between age at } \\
\text { onset of psoriasis and } \\
\text { comorbidities during } \\
\text { adulthood }\end{array}$ & $\begin{array}{l}\text { Frequency of obesity, } \\
\text { dyslipidemia, hypertension, } \\
\text { diabetes and MACEs in } \\
\text { adulthood according to age at } \\
\text { onset of psoriasis }\end{array}$ \\
\hline 9 & Goldminz 2013 USA [21-23] & Case-control & $9-<18$ & $20(5 \mathrm{M} / 15 \mathrm{~F}) / 20(5 \mathrm{M} / 15 \mathrm{~F})$ & Dermatologists & $\begin{array}{l}\text { Frequency of metabolic } \\
\text { syndrome }\end{array}$ & $\begin{array}{l}\text { Overweight and obesity, } \\
\text { dyslipidemia, diabetes, } \\
\text { hypertension, metabolic } \\
\text { syndrome }\end{array}$ \\
\hline 10 & Becker 2014 USA [24] & Retrospective & $4-17$ & $27(13 \mathrm{M} / 14 \mathrm{~F}) / \mathrm{NA}$ & Dermatologists & $\begin{array}{l}\text { Temporal association of } \\
\text { pediatric psoriasis and } \\
\text { increased adiposity }\end{array}$ & $\begin{array}{l}\text { Chronologic link between } \\
\text { overweight/obesity and } \\
\text { psoriasis onset }\end{array}$ \\
\hline 11 & Torres 2014, Portugal [25] & Case-control & $5-<16$ & $20(7 \mathrm{M} / 13 \mathrm{~F}) / 27(9 \mathrm{M} / 18 \mathrm{~F})$ & Dermatologists & Frequency of comorbidities & $\begin{array}{l}\text { Overweight and obesity, } \\
\text { dyslipidemia, diabetes, } \\
\text { hypertension, metabolic } \\
\text { syndrome }\end{array}$ \\
\hline 12 & Jensen 2014 Denmark [13] & Case-control & $10-<18$ & $30(16 \mathrm{M} / 14 \mathrm{~F}) / 30(16 \mathrm{M} / 14 \mathrm{~F})$ & Dermatologists & Cardiovascular risk factors & $\begin{array}{l}\text { Overweight and obesity, } \\
\text { dyslipidemia, diabetes, } \\
\text { hypertension, MACEs }\end{array}$ \\
\hline 13 & Augustin 2015 Germany [11] & National registry (GEK 2009) & $<18$ & $1313(\mathrm{NR}) / 291,868(\mathrm{NR})$ & ICD-10 code ( $\left(\mathrm{L} 40^{\mathrm{a}}\right)$ & $\begin{array}{l}\text { Analysis of comorbidity } \\
\text { reporting bias and confirmation } \\
\text { of frequency of comorbidities }\end{array}$ & $\begin{array}{l}\text { Overweight and obesity, } \\
\text { dyslipidemia, diabetes, } \\
\text { hypertension, MACEs }\end{array}$ \\
\hline 14 & Mahé 2015 France [26] & Case-control, multicenter & $2-<18$ & $\begin{array}{l}261(126 \mathrm{M} / 135 \mathrm{~F}) / 261(126 \mathrm{M} / \\
135 \mathrm{~F})\end{array}$ & Dermatologists & $\begin{array}{l}\text { Frequency of overweight and } \\
\text { obesity }\end{array}$ & $\begin{array}{l}\text { Overweight and obesity, } \\
\text { dyslipidemia, diabetes, } \\
\text { hypertension }\end{array}$ \\
\hline 15 & Lee 2016 Australia [27] & Case-control, multicenter & $5-<16$ & $135(62 \mathrm{M} / 73 \mathrm{~F}) / 73(36 \mathrm{M} / 37 \mathrm{~F})$ & Dermatologists & $\begin{array}{l}\text { Analysis of central adiposity, } \\
\text { metabolic syndrome and BMI }\end{array}$ & $\begin{array}{l}\text { Overweight and obesity, } \\
\text { hypertension, metabolic } \\
\text { syndrome }\end{array}$ \\
\hline 16 & Tom 2016 USA [28] & Case-control & $0-<18$ & $44(19 \mathrm{M} / 25 \mathrm{~F}) / 44(19 \mathrm{M} / 25 \mathrm{~F})$ & Dermatologists & $\begin{array}{l}\text { Lipoprotein composition and } \\
\text { function }\end{array}$ & $\begin{array}{l}\text { Overweight and obesity, } \\
\text { dyslipidemia, diabetes, } \\
\text { hypertension }\end{array}$ \\
\hline
\end{tabular}

F, female; M, male; NA, not applicable; NR, not reported; ICD-8, ICD-9, ICD-10, International Statistical Classification of Diseases and Related Health Problems, 8th, 9th, 10th revision.

a Including: Cases: Brazil, Canada, Chile, United States, Italy, Netherlands, Turkey, United Kingdom and Malaysia; Controls: United States, Netherlands, Italy and Malaysia. 
A. Badaoui et al./Archives de Pédiatrie $x x x$ (2018) $x x x-x x x$

\begin{tabular}{|c|}
\hline $\begin{array}{r}377 \text { articles found on PubMed and Ovid using key_-words "psoriasis" in combination with } \\
\text { "children or childhood or adolescent" and "obesity" or "hypertension" or "diabetes" or } \\
\text { "dyslipidemia" or "cardiovascular risk factor" }\end{array}$ \\
$\downarrow$ \\
\hline \\
\hline \\
\hline \\
\hline
\end{tabular}

Fig. 1. Flow chart

\subsection{Dyslipidemia}

Eight studies reported data on dyslipidemia. Dyslipidemia was defined in one study as LDL and/or TG $>95$ th age- and genderspecific percentile and/or $\mathrm{HDL}<5$ th percentile, and was reported as an ICD-10 code in two other studies. The other five studies compared levels of total cholesterol, LDL, HDL, TG, or other lipid proteins such as VLDL or apolipoproteins between psoriasis and control groups (Table 3 ).

Two studies (studies 2,13) reported higher prevalence of dyslipidemia in the psoriasis group using the ICD-10 code and two (studies 11,14) no difference. Three studies (studies 9, 12, 16) reported no difference in total or LDL-cholesterol, five (studies 5, 9, $11,12,16$ ) no difference in HDL-cholesterol, four (studies 9, 11, 12, 16) no difference in triglyceridemia, two (studies 12,16 ) no difference in other lipid proteins such as VLDL or apolipoproteins, except for two specific proteins: apolipoprotein B and large-HDL (study 16). One study (study 5) reported a higher level of total cholesterol and LDL in the psoriasis group without reaching the threshold for hyperlipidemia.

\subsection{Diabetes/insulin resistance}

Data on diabetes were reported in seven studies. Diabetes was defined in one study as fasting blood glucose $>126 \mathrm{mg} / \mathrm{dL}$ or $\mathrm{HbA}_{1 \mathrm{c}} \geq 6.5 \%$; homeostatic model assessment (HOMA) for insulin resistance $>3.16$ in four studies, and ICD-10 code in two studies. There was no definition of diabetes in the other five studies (Table 4).

One study (study 2) reported a significantly higher risk of diabetes in children with psoriasis. Two other studies (studies 9 , 12) reported higher plasma glucose but without reaching the threshold for diabetes, and one (study 16) reported higher logtransformed HOMA. The other six studies (studies 9, 12-14, 16) reported no difference in diabetes according to psoriasis status.

\subsection{Hypertension}

Data on hypertension were reported in nine studies. Hypertension was defined in four studies as: arterial blood pressure $>$ 90th percentile in one, diastolic and/or systolic blood pressure $>95$ th percentile in one, and by ICD-10 code in two studies (Table 5).

Two studies (studies 2,13) reported significantly higher prevalence of hypertension in children with psoriasis, using the ICD-10 code, two (studies 8, 12) reported higher systolic blood pressure without reaching the threshold for hypertension, two (studies 8,12 ) higher diastolic blood pressure without reaching the threshold for hypertension, two (studies 11,14 ) no difference in diastolic/systolic/blood pressure, and four (studies $8,9,15,16$ ) no difference in systolic or diastolic blood pressure.

\subsection{Metabolic syndrome}

Data on metabolic syndrome were reported in three studies. Definitions are detailed in Table 6. Only one study (study 9) showed higher prevalence of metabolic syndrome in children with psoriasis; the two other (studies 11,15 ) reported no difference. One (study 15 ) reported no correlation with severity of psoriasis.

\subsection{Cardiovascular risks, dysfunction, or MACEs}

Four studies reported data on cardiovascular risks, dysfunction, or adverse events (stroke, ischemic heart disease, or reactive hyperemia index (RHI)). The cumulative prevalence of ischemic heart disease was defined by ICD-10 code in two studies, cardiovascular risk by WtRH $>0.49$ in one (study 7), and cardiovascular dysfunction by RHI in one (measure of endothelial function) (study 12) (Table 7).

Two studies (studies 2,13) reported no difference in prevalence of ischemic heart disease. Interestingly, ischemic heart disease was reported in $0.75 \%$ of cases in one study (study 2 ) and in $0.08 \%$ in another (study 13), although these studies used the same methodology in the same population. One study (study 7) reported higher WtHR in the psoriasis group but without reaching the threshold for intermediate cardiovascular risk. One study (study 12 ) reported no difference in RHI.

\subsection{Chronologic links between childhood psoriasis and comorbidities}

Four studies assessed possible chronologic links between childhood psoriasis and onset of comorbidity (studies 3, 4, 8, 10). Two (studies 3,10 ) assessed possible correlation between age at onset of psoriasis and BMI in adulthood. One (study 3 ) reported significantly higher BMI in adulthood in patients with adult compared to childhood onset of psoriasis ( 26.8 vs. $24.2 ; P=0.015$ ) on univariate analysis (no multivariate analysis performed). One (study 4) reported that higher BMI at the age of 12-13 years was associated with hospital admission for psoriasis in adulthood. One (study 10) reported that overweight or obesity preceded psoriasis by more than 2 years in $93 \%$ of children suffering from psoriasis. 
Table 2

Childhood psoriasis, overweight, and obesity.

\begin{tabular}{|c|c|c|c|}
\hline No. & Studies & Definition of overweight and obesity & Results: psoriasis vs. control \\
\hline 1 & Boccardi 2009, Italy [16] & $\begin{array}{l}\text { Overweight: current weight/50th percentile weight at } \\
\text { age }>110 \%\end{array}$ & $\begin{array}{l}\text { Overweight: } 42 \text { ( } 48 \%) \text { vs. } 24 \text { (27\%). Odds ratio (95\% CI): } 2.55 \\
(1.31-4.96)\end{array}$ \\
\hline 2 & Augustin 2010, Germany [2] & ICD-10 Code $\left(\mathrm{E} 66^{\mathrm{a}}\right)$ & $8.40 \%$ vs. $4.90 \%$. Prevalence (95\% CI): $1.70(1.49-1.93)$ \\
\hline 4 & Bryld 2010, Denmark [18] & $\begin{array}{l}\text { NR (comparison of BMI and deviation from BMI z-score for } \\
\text { age and gender) }\end{array}$ & $\begin{array}{l}\text { No difference in BMI for males aged } 7-13 \text { years or girls aged } 7 \text { - } \\
11 \text { years. Girls, } 12 \text { years, BMI z-score: } 0.161 \text { vs. } 0.061 \text {; } \\
P=0.028 \text { Girls, } 13 \text { y, BMI z-score: } 0.205 \text { vs. } 0.084 ; P=0.010\end{array}$ \\
\hline 5 & Koebnick 2011, USA [12] & $\begin{array}{l}\text { Overweight: } \mathrm{BMI}>85 \text { th and }<95 \text { th percentile or } \\
\text { BMI } \geq 25 \mathrm{~kg} / \mathrm{m}^{2} \text { and }<30 \mathrm{~kg} / \mathrm{m}^{2} \text { Obesity: } \mathrm{BMI}>95 \text { th } \\
\text { percentile or BMI } \geq 30 \mathrm{~kg} / \mathrm{m}^{2} \text { Extremely obese: } \\
\text { BMI } \times 1.2 \geq 95 \text { th percentile or BMI } \geq 35 \mathrm{~kg} / \mathrm{m}^{2}\end{array}$ & $\begin{array}{l}\text { Overweight: OR (95\% CI): } 1.30(1.14-1.49) \text { Moderate obesity: } \\
\text { OR }(95 \% \mathrm{CI}): 1.38(1.18-1.62) \text { Extreme obesity: OR }(95 \% \mathrm{CI}) \text { : } \\
1.78(1.48-2.14) \text { Increased association with disease severity }\end{array}$ \\
\hline 6 & Zhu 2011, China [19] & International Obesity Task Force (IOTF) definition & $\begin{array}{l}\text { Overweight: } 52(15.7 \%) \text { vs. } 11(7.5 \%) \text { OR (95\% IC): } 2.4(1.2-4.8) \text {; } \\
P<0.0 \text { Obesity: } 30(9.0 \%) \text { vs. } 6(4.1 \%) . \text { OR (95\% IC): } 2.6(1.0-6.4) \text {; } \\
P<0.05 \text {. Disease severity was associated with BMI }{ }^{\text {b }}\end{array}$ \\
\hline 7 & Paller 2012, International [14] & $\begin{array}{l}\text { Overweight: } \mathrm{BMI} \geq 85 \text { th and }<95 \text { th percentile (CDC curves) } \\
\text { or } \mathrm{BMI} \geq 25 \mathrm{~kg} / \mathrm{m}^{2} \text { and }<30 \mathrm{~kg} / \mathrm{m}^{2} \text { Obesity } \geq 95 \text { th } \\
\text { percentile (CDC curves) or } \mathrm{BMI} \geq 30 \mathrm{~kg} / \mathrm{m}^{2}\end{array}$ & 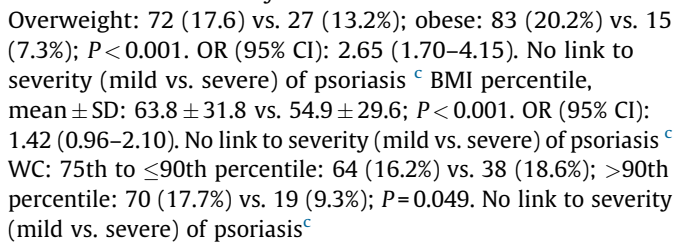 \\
\hline 9 & Goldminz 2013, USA [21-23] & NR (comparisons of BMI and WC) & $\begin{array}{l}\text { BMI }\left(\mathrm{kg} / \mathrm{m}^{2}\right), \text { mean } \pm \text { SD: } 22.5 \pm 5.4 \text { vs. } 22.7 \pm 5.7 ; P=0.89 \text { WC } \\
(\mathrm{cm}), \text { mean } \pm \text { SD: } 81.1 \pm 16 . \text { vs. } 077.6 \pm 13.2 ; P=0.42\end{array}$ \\
\hline 11 & Torres 2014, Portugal [25] & $\begin{array}{l}\text { Overweight: BMI }>85 \text { th percentile, WC }>75 \text { th percentile } \\
\text { Obesity }>95 \text { th percentile, } W C>90 \text { th percentile }\end{array}$ & $\begin{array}{l}\text { Overweight: } 7(35 \%) \text { vs. } 6(22.2 \%) \text {; obesity: } 4(25 \%) \text { vs. } 1(3.7 \%) \text {; } \\
P=0.03 \text { WC }>75 \text { th percentile: } 10(50 \%) \text { vs. } 4(14.8 \%) ; \text { WC }>90 \text { th } \\
\text { percentile: } 4(25 \%) \text { vs. } 10(14.8 \%) ; P=0.015 \mathrm{BMI}\left(\mathrm{kg} / \mathrm{m}^{2}\right) \text {, } \\
\text { mean } \pm \text { SD: } 21.1 \pm 4.0 \text { vs. } 19.0 \pm 2.9 ; P=0.011 \mathrm{WC}(\mathrm{cm}), \\
\text { mean } \pm \text { SD: } 73.5 \pm 11.7 \text { vs. } 67.9 \pm 10.1 ; P=0.028\end{array}$ \\
\hline 12 & Jensen 2014, Denmark [13] & NR (comparisons of BMI and WC) & $\begin{array}{l}\text { BMI }\left(\mathrm{kg} / \mathrm{m}^{2}\right), \text { mean } \pm S D: 20.3 \pm 0.6 \text { vs. } 18.7 \pm 0.5 ; P=0.036 \mathrm{WC} \\
(\mathrm{cm}), \text { mean } \pm \mathrm{SD}: 72.0 \pm 1.8 \text { vs. } 66.0 \pm 1.0 ; P=0.004\end{array}$ \\
\hline 13 & Augustin 2015, Germany [11] & ICD-10 Code $\left(\mathrm{E}^{\mathrm{a}} 6^{\mathrm{a}}\right)$ & $7.08 \%$ vs. $3.61 \%$. Prevalence rate $(95 \% \mathrm{CI}): 1.89(1.53-2.34)$ \\
\hline 14 & Mahé 2015, France [26] & $\begin{array}{l}\text { Overweight: BMI > 90th percentile (French curves) } \\
\text { Obesity: BMI > IOTF-30 (International definition) } \\
\text { Abdominal obesity: WtHR }>0.5\end{array}$ & $\begin{array}{l}\text { Overweight: } 6(2.3 \%) \text { vs. } 15(5.7 \%) ; P=018 \text { Overweight with } \\
\text { abdominal obesity: } 22(8.4 \%) \text { vs. } 19(7.3 \%) . P=0.009 \text { Obesity: } 26 \\
(10.0 \%) \text { vs. } 8(3.1 \%) . P=0.001 \text { Frequency higher in females } \\
(P=0.048) \text {, if overweight in parents }(P<0.02) \text {. No impact of } \\
\text { disease severity }{ }^{\mathrm{a}} \text { or clinical type of psoriasis }\end{array}$ \\
\hline 15 & Lee 2016, Australia [27] & $\begin{array}{l}\text { Overweight: } \mathrm{BMI}>85 \text { th percentile Obesity: } \mathrm{BMI}>95 \text { th } \\
\text { percentile Increased central obesity: WtHR }>0.5\end{array}$ & 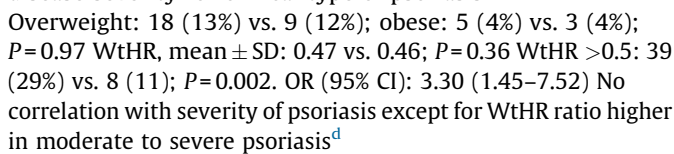 \\
\hline 16 & Tom 2016, USA [28] & $\begin{array}{l}\text { Overweight: } \mathrm{BMI}>85 \text { th to } \leq 95 \text { th percentile Obesity: } \\
\text { BMI }>95 \text { th percentile }\end{array}$ & $\begin{array}{l}\text { Overweight: } 20 \% \text { vs. } 16 \% \text { Obesity: } 27 \% \text { vs. } 9 \% \text { BMI }\left(\mathrm{kg} / \mathrm{m}^{2}\right) \text {, } \\
\text { mean } \pm \text { SD: } 23.5 \pm 6.1 \text { vs. } 21.4 \pm 4 ; P=0.03 \text { WC }(\mathrm{cm}), \text { mean } \pm S D \text { : } \\
80.5 \pm 17.9 \text { vs. } 74.3 \pm 12.5 ; P=0.04 \text { WtHR, mean } \pm \text { SD: } \\
0.85 \pm 0.06 \text { vs. } 0.80 \pm 0.06 ; P<0.001\end{array}$ \\
\hline
\end{tabular}

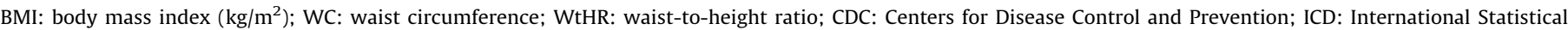

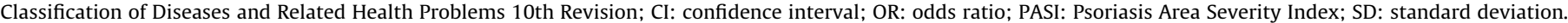

a Severity of psoriasis defined by the use of systemic treatments.

b Severity of psoriasis defined by PASI.

c Severity of psoriasis definition: mild psoriasis = worst Physician's Global Assessment score 1 or 2, or 3 with body surface area (BSA) $\leq 10 \%$; severe= worst Physician's Global Assessment score 4 or 5 , or 3 with BSA $>10 \%$.

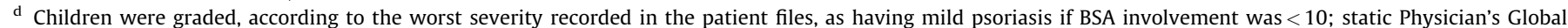
Assessment (sPGA) score, $\leq 2$; and Psoriasis Activity Severity Index (PASI) $<10$; and moderate to severe psoriasis if BSA $\geq 10$; SPGA $>2$; or PASI $\geq 10$.

Finally, one study (study 8) analyzed the frequency of obesity, dyslipidemia, hypertension, diabetes, and MACEs in adulthood according to age of onset of psoriasis and found no significant difference between the age of onset and the frequency of comorbidities in adulthood (Table 8).

\section{Discussion}

Over the past 10 years, there has been an increase in the number of studies confirming links between psoriasis and metabolic and cardiovascular comorbidities in adults. In children, the studies we analyzed revealed significantly higher risk of overweight and obesity in children with psoriasis, despite the variety of definitions used for overweight and obesity. A correlation was found between overweight and/or obesity and severity of psoriasis in only two studies but was not confirmed by three others. These results are, however, difficult to compare, due to the differences in definitions of overweight and obesity. Since 2000, definitions of overweight and obesity in children have been consensually based on international data and linked to the widely accepted adult cutoff points of BMI $25 \mathrm{~kg} / \mathrm{m}^{2}$ and $30 \mathrm{~kg} / \mathrm{m}^{2}$ [29], although other definitions also exist. This link could be explained by induction of psoriasis by cytokines coming from adipose tissue.

Eight studies reported data on dyslipidemia. The two studies reporting significantly higher prevalence of dyslipidemia in psoriasis used an ICD-10 code definition. None of the other studies in which lipoproteins were measured reported higher risk of dyslipidemia in children with psoriasis. It should be noted that there is no consensual definition of dyslipidemia in children. The American Heart Association [30] and the American Academy of Pediatrics [31] set a cut-off point for LDL-cholesterol (LDLC) at $1.90 \mathrm{~g} / \mathrm{L}$ in children with no comorbidities, but with slight differences according to age and type of comorbidity. The 
Table 3

Childhood psoriasis and dyslipidemia.

\begin{tabular}{|c|c|c|c|}
\hline No. & Studies & Definition of dyslipidemia & Results: psoriasis vs. control \\
\hline 2 & Augustin 2010, Germany [2] & ICD-10 code $\left(\mathrm{E}^{\mathrm{a}} 8^{\mathrm{a}}\right)$ & $2.12 \%$ vs. $0.99 \%$. Prevalence rate $(95 \% \mathrm{CI}): 2.15(1.65-2.80)$ \\
\hline 5 & Koebnick 2011, USA [12] & NR (measurement of LDL, HDL, total cholesterol, and TG) & $\begin{array}{l}\text { Among overweight and obese patients: Total cholesterol, mg/ } \\
\mathrm{dL} \text {, mean } \pm \mathrm{SD}: 169.6 \pm 4.2 \text { vs. } 163.9 \pm 3.6 ; P=0.021 \mathrm{HDL}- \\
\text { cholesterol, mg/dL, mean } \pm \text { SD: } 45.3 \pm 2.9 \text { vs. } 45.4 \pm 2.8 \\
P=0.937 \mathrm{LDL}-\text { cholesterol, } \mathrm{mg} / \mathrm{dL}, \text { mean } \pm \mathrm{SD}: 103.9 \pm 4.1 \mathrm{vs} \text {. } \\
98.4 \pm 3.5 ; P=0.007 \mathrm{TG}, \mathrm{mg} / \mathrm{dL} \text {, mean } \pm \mathrm{SD}: 114.4 \pm 16.4 \mathrm{vs} \text {. } \\
100.6 \pm 13.8 ; P=0.015\end{array}$ \\
\hline 9 & Goldminz 2013, USA [21-23] & NR (measurement of LDL, HDL, total cholesterol, and TG) & $\begin{array}{l}\text { Total cholesterol, } \mathrm{mg} / \mathrm{dl}, \text { mean } \pm \text { SD: } 152.9 \pm 36.09 \mathrm{vs.} \\
156.3 \pm 23 ; P=0.75 \mathrm{HDL} \text { cholesterol, } \mathrm{mg} / \mathrm{dL}, \text { mean } \pm \mathrm{SD} \text { : } \\
44.3 \pm 9.5 \text { vs. } 49.7 \pm 8.9 ; P=0.16 \mathrm{LDL} \text { cholesterol, } \mathrm{mg} / \mathrm{dL} \\
\text { mean } \pm \text { SD: } 95.1 \pm 32.5 \text { vs. } 95.1 \pm 19.2 ; P>0.99 \mathrm{TG}, \mathrm{mg} / \mathrm{dL} \\
\text { mean } \pm \mathrm{SD}: 68.0 \pm 26.2 \text { vs. } 58.4 \pm 17.4 ; P=0.24\end{array}$ \\
\hline 11 & Torres 2014, Portugal [25] & $\begin{array}{l}\text { LDL and/or TG }>95 \text { th age-, sex-specific percentile and/or } \\
\text { HDL }<5 \text { th percentile }\end{array}$ & $\begin{array}{l}\text { HDL-C }<50 \mathrm{mg} / \mathrm{dL} .8(40 \%) \text { vs. } 10(37 \%) ; P=1 \mathrm{TG} \geq 100 \mathrm{mg} / \mathrm{dL}: 2 \\
(10 \%) \text { vs. } 2(7.4 \%) ; P=1 \text { Dyslipidemia: } 3(15 \%) \text { vs. } 2(7.4 \%) ; \\
P=0.68\end{array}$ \\
\hline 12 & Jensen 2014, Denmark [13] & NR (measurement of LDL, HDL, VLDL, total cholesterol, and TG) & $\begin{array}{l}\text { Total cholesterol, mmol/L, mean } \pm \text { SD: } 3.8 \pm 0.1 \text { vs. } 3.9 \pm 1.4 ; \\
P=0.702 \text { HDL cholesterol, mmol/L, mean } \pm \text { SD: } 1.25 \pm 0.05 \text { vs. } \\
1.29 \pm 0.06 ; P=0.519 \text { LDL cholesterol, mmol/L, mean } \pm \text { SD: } \\
2.1 \pm 0.1 \text { vs. } 2.2 \pm 0.1 ; P=0.67 \text { VLDL cholesterol, mmol/L, median } \\
(\mathrm{IQR}): 0.4(0.2-0.6) \text { vs. } 0.4(0.3-0.4) ; P=0.913 \mathrm{TG}, \mathrm{mmol} / \mathrm{L} \text {, } \\
\text { mean } \pm \text { SD } 0.96 \pm 0.09 \text { vs. } 0.95 \pm 0.10 ; P=0.876\end{array}$ \\
\hline 13 & Augustin 2015, Germany [11] & ICD-10 code $\left(\mathrm{E}^{\mathrm{a}} \mathrm{8}^{\mathrm{a}}\right)$ & $1.14 \%$ vs. $0.64 \%$. Prevalence (95\% CI): 1.79 (1.08-2.99) \\
\hline 14 & Mahé 2015, France [26] & NR (diagnosis declared by dermatologist) & $7(3.0 \%)$ vs. $2(0.8 \%) ; P=0.08$ \\
\hline 16 & Tom 2016, USA [28] & $\begin{array}{l}\text { NR (measurement of LDL, HDL, VLDL, total cholesterol, Apo, and } \\
\text { TG) }\end{array}$ & $\begin{array}{l}\text { No differences for: total cholesterol, LDL-cholesterol, HDL- } \\
\text { cholesterol, TG, Apo A, VLDL particles, LDL particles } \\
\text { Apo B, mg/dL, mean } \pm \text { SD: } 72.4 \pm 18.1 \text { vs. } 64.6 \pm 16.2 ; P=0.02 \\
\text { Large HDL-particle, } \mu \text { mol/L, mean } \pm \text { SD: } 5.3 \pm 2.9 \text { vs. } 6.7 \pm 2.5 \text {; } \\
P<0.01 \text { Cholesterol efflux capacity, mean } \pm \text { SD: } 0.90 \pm 015 \text { vs. } \\
0.95 \pm 0.12 . P=0.002\end{array}$ \\
\hline
\end{tabular}

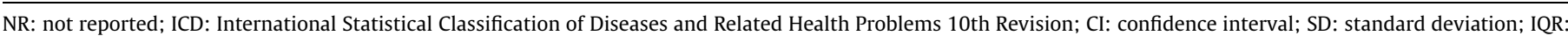
interquartile range; TG: triglycerides; Apo: apolipoprotein.

definition may vary according to children's origin. For example, two French studies reported a 95th percentile for LDLc of $1.64 \mathrm{~g} / \mathrm{L}$ and $1.49 \mathrm{~g} / \mathrm{L}$ in males and $1.74 \mathrm{~g} / \mathrm{L}$ and $1.55 \mathrm{~g} / \mathrm{L}$ in females [32-34], which is lower than the American cut-off. The absence of a consensual definition casts doubt on the relevance of the ICD-10 code used in the two studies reporting a significant difference, and a higher risk of dyslipidemia in children with psoriasis cannot be said to have been demonstrated.

Seven studies reported data on diabetes and insulin resistance, only one finding a significantly higher risk of diabetes in psoriasis. This study reported diabetes using an ICD-10 code, and we tend to believe the findings could be irrelevant, given that the ICD-10 code and registry studies can show several biases. Moreover, the same type of study conducted 5 years later found no significant difference between psoriasis patients and controls. Other studies reported higher plasma glucose levels, but without reaching the threshold for diabetes, and one reported a higher log-transformed HOMA, suggesting a link between insulin resistance and psoriasis. An increased inflammatory state is indeed associated with both insulin resistance and psoriasis and could explain this link.

Nine studies reported data on hypertension, only two finding a significantly higher risk of hypertension in children with psoriasis. These studies also used an ICD-10 code to define hypertension, which may have led to biases. Two other studies reported higher systolic or diastolic blood pressure in children with psoriasis, but without reaching the threshold for hypertension, and with differences that were subclinical ( 4 or $6 \mathrm{mmHg}$ ). Moreover, the definition of hypertension in children is not consensual, although usually taken as $>95$ th percentile for gender, age, and height [35]. Therefore, a higher risk of hypertension in children with psoriasis has not been demonstrated.

Very few studies reported data on metabolic syndrome and MACEs. In adults, six different definitions of metabolic syndrome were published between 1988 and 2005 [36-41]. Metabolic syndrome is related to a higher risk of adverse cardiovascular events in adults, but its definition in children is still debated. Mimoun et al. [42] suggested that the value of metabolic syndrome as a predictor of future cardiovascular events was unclear in children and needed further prospective studies. We therefore do not believe that metabolic syndrome should be analyzed as a criterion in childhood psoriasis until it is clearly defined in children. In a recent meta-analysis, Pietrzak et al. [43] assessed metabolic disorder in children with psoriasis, analyzing data from seven studies with a total of 965 children. Three of the seven studies assessed prevalence of metabolic syndrome, and in all three the rate of metabolic syndrome was significantly higher in case of psoriasis. The authors also showed a significantly higher concentration of fasting glucose and a lower level of HDLcholesterol in patients with psoriasis but without reaching the abnormal cut-off.

None of the four studies reporting data on MACEs, cardiovascular risk, or dysfunction showed a difference between children with psoriasis and controls. Surprisingly, Augustin et al. [2] reported a $0.75 \%$ cumulative prevalence of ischemic heart disease in children with psoriasis, which does not correspond to real life: the rate seems very high and is even higher than in another study they published 5 years later using the same methodology, suggesting a probable bias in the ICD-10 code.

One of the four studies analyzing a potential chronologic link between childhood psoriasis and comorbidities reported a correlation with BMI in adulthood, but with a slightly significantly higher mean BMI in patients with adult rather than childhood onset of psoriasis. Becker et al. [24] reported a potential link between overweight/obesity and child psoriasis, overweight or obesity preceding psoriasis by more than 2 years in $93 \%$ of children with psoriasis. Bryld et al. [18] also reported a link between obesity and psoriasis, showing that high BMI in 12- to 13-year-old girls was associated with more severe psoriasis leading to hospital admission. However, the only group showing a significant difference in their study was 12- to 13-year-old girls, without 
Table 4

Childhood psoriasis and diabetes/insulin resistance.

\begin{tabular}{|c|c|c|c|}
\hline No. & Studies & Definition of diabetes & Results: psoriasis vs. control \\
\hline 2 & Augustin 2010, Germany [2] & ICD-10 Code (E11, E13, E14) & $0.86 \%$ vs. $0.43 \%$. Prevalence $(95 \%$ CI): $2.01(1.32-3.04)$ \\
\hline 9 & Goldminz 2013, USA [21-23] & NR (comparison of fasting blood glucose) & Glucose, g/dL, mean \pm SD: $91.1 \pm 7.4$ vs. $82.9 \pm 10.3 ; P=0.01$ \\
\hline 11 & Torres 2014, Portugal [25] & $\begin{array}{l}\text { Fasting blood glucose }>126 \mathrm{mg} / \mathrm{dL} \text { or } \mathrm{HbA} 1 \mathrm{c} \geq 6.5 \% \text { Insulin } \\
\text { resistance: HOMA }>3.16\end{array}$ & $\begin{array}{l}\text { Diabetes: } 0 \text { vs. } 0 \text { Insulin resistance: } 1 \text { (5\%) vs. } 3(11.1 \%) \text {; } \\
P=0.6\end{array}$ \\
\hline 12 & Jensen 2014, Denmark [13] & $\begin{array}{l}\text { NR (comparison of fasting blood glucose, and glycated } \\
\text { hemoglobin) }\end{array}$ & $\begin{array}{l}\text { Glucose, } \mathrm{mmol} / \mathrm{L}, \text { mean } \pm \mathrm{SD}: 5.3 \pm 0.2 \text { vs. } 4.9 \pm 0.10 \\
P=0.043 \text { Glycated hemoglobin, } \% \text {, mean } \pm \text { SD } 5.25 \pm 0.11 \text { vs. } \\
5.19 \pm 0.04 ; P=0.596\end{array}$ \\
\hline 13 & Augustin 2015, Germany [11] & ICD-10 Code (E11, E13, E14) & $0.61 \%$ vs. $0.31 \%$. Prevalence (95\% CI): 1.97 (0.98-3.96) \\
\hline 14 & Mahé 2015, France [26] & NR (diagnosis by dermatologist) & 0 vs. 0 \\
\hline 16 & Tom 2016, USA [28] & NR (comparison of insulin resistance: HOMA-IR) & $\begin{array}{l}\text { Glucose, } \mathrm{mg} / \mathrm{dL} \text {, mean } \pm \mathrm{SD}: 79.5 \pm 7.8 \text { vs. } 80.1 \pm 8.1 \\
P=0.63 \text { HOMA-IR } 2.41 \pm 1.83 \text { vs. } 1.99 \pm 1.38 ; P=0.11 \text { Log- } \\
\text { transformed HOMA-IR } 0.65 \pm 0.68 \text { vs. } 0.41 \pm 0.88 ; P=0.07\end{array}$ \\
\hline
\end{tabular}

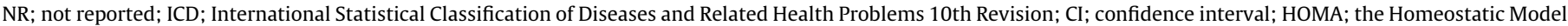
Assessment for Insulin Resistance; SD; standard deviation.

Table 5

Childhood psoriasis and hypertension.

\begin{tabular}{|c|c|c|c|}
\hline No. & Studies & Definition of hypertension & Results: psoriasis vs. control \\
\hline 2 & Augustin 2010, Germany [2] & ICD-10 code $\left(110^{*} \ldots \mathrm{I} 13^{*}\right)$ & $1.5 \%$ vs. $0.83 \%$. Prevalence $(95 \% \mathrm{CI}): 1.89(1.47-2.67)$ \\
\hline 7 & Paller 2012, International [14] & NR (comparison of BP) & $\begin{array}{l}\text { International evaluation: Systolic BP }(\mathrm{mmHg}) \text {, mean } \pm \mathrm{SD} \text { : } \\
110 \pm 12 \text { vs. } 114 \pm 11 ; P=0.008 \text { Diastolic } \mathrm{BP}(\mathrm{mmHg}) \text {, mean } \pm \mathrm{SD} \text { : } \\
67 \pm 8 \text { vs. } 66 \pm 9 ; P=0.80 \text { In US participants: Systolic BP }(\mathrm{mmHg}) \text {, } \\
\text { mean } \pm \text { SD: } 110 \pm 12 \text { vs. } 110 \pm 12 ; P=0.74 \text { Diastolic BP }(\mathrm{mmHg}) \text {, } \\
\text { mean } \pm \text { SD: } 67 \pm 8 \text { vs. } 64 \pm 10 ; P=0.46 \text {. Diastolic BP higher in mild } \\
\text { psoriasis }(P=0.049)\end{array}$ \\
\hline 9 & Goldminz 2013, USA [21-23] & Arterial blood pressure $>90$ th percentile & $\begin{array}{l}\text { Systolic BP }(\mathrm{mmHg}) \text {, mean } \pm \text { SD: } 111.7 \pm 8.5 \text { vs. } 110.2 \pm 9.5 ; \\
P=0.64 \text { Diastolic } B P(\mathrm{mmHg}) \text {, mean } \pm \text { SD: } 70.9 \pm 8.5 \text { vs. } 69.8 \pm 5.6 \text {; } \\
P=0.65\end{array}$ \\
\hline 11 & Torres 2014, Portugal [25] & $\begin{array}{l}\text { Systolic and/or diastolic BP } \geq \text { the } 95 \text { th age-, sex-, and } \\
\text { height-specific percentile }\end{array}$ & $\begin{array}{l}\text { Hypertension: } 2(103 \%) \text { vs. } 1(3.7 \%) ; P=0.567 \text { Systolic BP/ } \\
\text { diastolic BP >90th percentile: } 6(30 \%) \text { vs. } 1(3.7 \%) ; P=0.032\end{array}$ \\
\hline 12 & Jensen 2014, Denmark [13] & NR (comparison of systolic and diastolic BP) & $\begin{array}{l}\text { Systolic BP }(\mathrm{mmHg}), \text { mean } \pm \text { SD: } 105 \pm 2 \text { vs. } 99 \pm 2 \text {; } \\
P=0.023 \text { Diastolic BP }(\mathrm{mmHg}) \text {, mean } \pm \text { SD: } 66 \pm 2 \text { vs. } 64 \pm 12 \text {; } \\
P=0.354\end{array}$ \\
\hline 13 & Augustin 2015, Germany [11] & ICD-10 code $\left(\mathrm{I} 10^{*} \ldots \mathrm{I} 13^{*}\right)$ & $0.91 \%$ vs. $0.44 \%$. Prevalence $(95 \% \mathrm{CI}): 2.09$ (1.18-3.69) \\
\hline 14 & Mahé 2015, France [26] & NR (diagnosis by dermatologist) & $2(0.8 \%)$ vs. $0(0 \%) ; p=0.15$ \\
\hline 15 & Lee 2016, Australia [27] & NR (comparison of BP) & $\begin{array}{l}\text { Systolic } B P(\mathrm{mmHg}), \text { mean } \pm \text { SD: } 104.6 \pm 10.1 \text { vs. } 102.8 \pm 12.3 ; \\
P=0.26 \text { Diastolic } \mathrm{BP}(\mathrm{mmHg}) \text {, mean } \pm \text { SD: } 66.5 \pm 5.8 \text { vs. } 66.7 \pm 7.1 \text {; } \\
P=0.80\end{array}$ \\
\hline 16 & Tom 2016, USA [28] & NR (comparison of BP) & $\begin{array}{l}\text { Systolic BP (mmHg), mean } \pm \text { SD: } 116 \pm 11 \text { vs. } 116 \pm 15 ; \\
P=0.57 \text { Diastolic BP }(\mathrm{mmHg}) \text {, mean } \pm \text { SD: } 63 \pm 9 \text { vs. } 66 \pm 9 ; P=0.1\end{array}$ \\
\hline
\end{tabular}

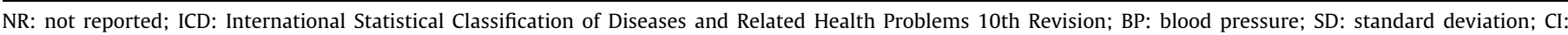
confidence interval.

Table 6

Childhood psoriasis and metabolic syndrome.

\begin{tabular}{|c|c|c|c|}
\hline No. & Studies & Definition of metabolic syndrome & Results (psoriasis vs. control) \\
\hline 9 & Goldminz 2013, USA [21-32] & $\begin{array}{l}\geq 3 \text { of the following: waist circumference } \geq 75 \text { th percentile } \\
\mathrm{TG} \geq 100 \mathrm{mg} / \mathrm{dL} \mathrm{HDL} \text {-cholesterol }<50 \mathrm{mg} / \mathrm{dL} \text { (or }<45 \mathrm{mg} / \mathrm{dL} \text { for boys } \\
\text { aged } 15-17 \text { years) fasting blood glucose } \geq 110 \mathrm{mg} / \mathrm{dL} \text { systolic or } \\
\text { diastolic blood pressure } \geq 90 \text { th percentile }\end{array}$ & 6 (30\%) vs. $1(5 \%) ; P<0.05$ \\
\hline 11 & Torres 2014, Portugal [25] & $\begin{array}{l}\geq 3 \text { of the following: waist circumference } \geq 75 \text { th percentile } \\
\mathrm{TG} \geq 100 \mathrm{mg} / \mathrm{dL} \mathrm{HDL} \text {-cholesterol }<50 \mathrm{mg} / \mathrm{dL} \text { fasting blood } \\
\text { glucose } \geq 110 \mathrm{mg} / \mathrm{dL} \text { systolic or diastolic blood pressure } \geq 90 \text { th } \\
\text { percentile }\end{array}$ & $4(25 \%)$ vs. $1(3.7 \%) ; P=0.07$ \\
\hline 15 & Lee 2016, Australia [27] & $\begin{array}{l}\text { Increased central adiposity ( } \geq 90 \text { th percentile, adjusted for sex and } \\
\text { race), and } \geq 2 \text { of the following (only if age } \geq 10 \text { years): TG } \geq 1.7 \mathrm{mmol} / \mathrm{L} \\
\text { HDL-cholesterol }<1.03 \text { in boys or } 1.29 \text { in girls or undergoing medical } \\
\text { therapy for low HDL-cholesterol systolic } \mathrm{BP} \geq 130 \mathrm{mmHg} \text { or diastolic } \\
\mathrm{BP} \geq 85 \mathrm{mmHg} \text { or undergoing treatment for previously diagnosed } \\
\text { hypertension fasting glucose level } \geq 5.6 \mathrm{mmol} \text { or previously diagnosed } \\
\text { type- } 2 \text { diabetes }\end{array}$ & $\begin{array}{l}4 / 53(8 \%) \text { vs. } 0 / 29(0 \%) \\
P=0.29 \text { No correlation with } \\
\text { disease severity }\end{array}$ \\
\hline
\end{tabular}

TG: triglycerides; BP: blood pressure. 
Table 7

Childhood psoriasis and cardiovascular risk, dysfunction, or MACEs.

\begin{tabular}{|c|c|c|c|}
\hline No. & Studies & Events evaluated & Results (psoriasis vs. control) \\
\hline 2 & Augustin 2010, Germany [2] & ICD-10 code (ischemic heart disease, $I 20^{\mathrm{a}} \ldots \mathrm{I} 25^{\mathrm{a}}$ ) & $0.75 \%$ vs. $0.49 \%$. Prevalence rate $(95 \% \mathrm{CI}): 1.52(0.97-2.38)$ \\
\hline 7 & Paller 2012, International [14] & $\begin{array}{l}\text { High cardiovascular risk: WtHR } \geq 0.539 \text { Intermediate } \\
\text { cardiovascular risk: WtHR } \geq 0.490\end{array}$ & 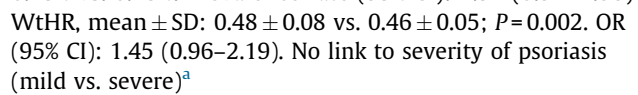 \\
\hline 12 & Jensen 2014, Denmark [13] & RHI (measurement of endothelial function) & $\begin{array}{l}\text { RHI, median (IQR): } 2.03(1.53-2.19) \text { vs. } 1.69(1.25-2.00) \text {; } \\
P=0.083\end{array}$ \\
\hline 13 & Augustin 2015, Germany [11] & ICD-10 code (ischemic heart disease, $\mathrm{I}^{2} 0^{\mathrm{a}}$ & $0.08 \%$ vs. $0.06 \%$. Prevalence (95\% CI): $1.27(0.18-9.07)$ \\
\hline
\end{tabular}

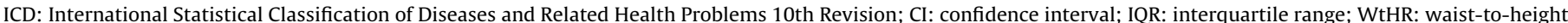

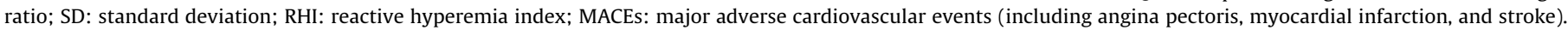

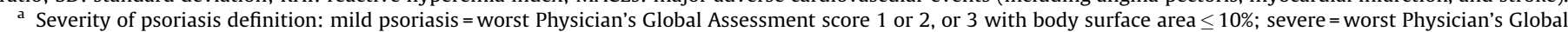
Assessment score 4 or 5 , or 3 with body surface area $>10 \%$.

Table 8

Chronologic links between child psoriasis and comorbidities.

\begin{tabular}{|c|c|c|c|}
\hline No. & Studies & Events evaluated & Results, AOP vs. COP \\
\hline 3 & De Jager 2010, Netherlands [17] & $\begin{array}{l}\text { BMI in adulthood according to age at onset of psoriasis } \\
\text { (COP/AOP); univariate analysis }\end{array}$ & $\begin{array}{l}\text { Correlation between age at onset and BMI: } \mathrm{r}=0.074 \text {; } \\
P=0.001 \mathrm{Mean} \text { BMI in adulthood: } 26.2 \pm 4.8 \mathrm{~kg} / \mathrm{m}^{2} \mathrm{vs} \text {. } \\
26.8 \pm 4.5 \mathrm{~kg} / \mathrm{m}^{2} ; P=0.015\end{array}$ \\
\hline 4 & Bryld 2010, Denmark [18] & $\begin{array}{l}\text { Links between obesity and hospital admission for psoriasis } \\
\text { in adulthood }\end{array}$ & $\begin{array}{l}\text { High BMI in } 12 \text { - to } 13 \text {-year-old girls is associated with } \\
\text { hospital admission for psoriasis in adulthood. Not found for } \\
\text { males or younger girls }\end{array}$ \\
\hline 8 & Mahé 2013, France [20] & $\begin{array}{l}\text { Frequency of obesity, dyslipidemia, hypertension, diabetes, } \\
\text { MACEs in adulthood according to age at onset of psoriasis } \\
\text { (COP/AOP); multivariate analysis }\end{array}$ & $\begin{array}{l}\text { No impact of age at onset of psoriasis on frequency of } \\
\text { comorbidities in adulthood }\end{array}$ \\
\hline 10 & Becker 2014, USA [24] & $\begin{array}{l}\text { Chronologic link between overweight/obesity and psoriasis } \\
\text { onset }\end{array}$ & $\begin{array}{l}\text { Overweight or obesity precedes psoriasis by }>2 \text { years in } \\
93 \% \text { of psoriatic children }\end{array}$ \\
\hline
\end{tabular}

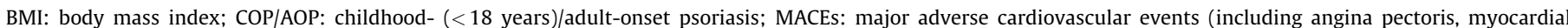
infarction, and stroke).

any significant results in younger girls or in males, which suggests a statistical bias. Moreover, severe psoriasis is difficult to define in children: severity is based on the Psoriasis Area Severity Index (PASI) or body surface area (BSA), and the usual definition of moderate-to-severe psoriasis is a score $>10$ on either scale, which has not been validated in children [44]. In contrast, Mahé et al. $[20,26]$ reported no impact of age of onset of psoriasis on the frequency of obesity, diabetes, hypertension, dyslipidemia, or MACEs.

All these results suggest that a link may exist between overweight/obesity and childhood psoriasis. They also suggest that overweight could induce psoriasis, and thus that screening for psoriasis could be contributive in all overweight and obese children, although no studies have clearly demonstrated this. However, there is no confirmed link between childhood psoriasis and other comorbidities. Therefore, there is no justification for systematic screening for other comorbidities. However, since acitretin may induce hyperlipidemia, cyclosporine hypertension, and anti-TNF-alpha weight gain [45], screening for these comorbidities should be performed before initiation of these treatments for psoriasis. Moreover, there is no evidence for an impact of familial hypercholesterolemia screening in childhood on lipid concentration or cardiovascular outcome in adulthood, or for any long-term beneficial or adverse effect of beginning lipidlowering treatment in childhood [46].

The present study had certain limitations. There was limited number of eligible studies, and the meta-analysis could not be performed due to the wide variability of definitions and methods.

\section{Conclusion}

Psoriasis in children is not associated with metabolic and cardiovascular comorbidities except overweight and obesity, for which higher prevalence is clearly demonstrated. Onset of psoriasis in childhood is not associated with higher risk of comorbidity in adulthood, but there seems to be a chronological link between overweight/obesity in childhood and psoriasis onset. Therefore, according to this systematic review of the literature, systematic screening is not warranted, but should be proposed for at-risk children: with obesity or family history of metabolic/ cardiovascular disease.

\section{Disclosure of interest}

A. Badaoui and P. Tounian declare they have no conflict of interest concerning this article.

E. Mahé has been a consultant for Novartis, Abbvie, Boehringer Ingelheim, Celgene, Leo Pharma, and Janssen Cilag; has been an investigator for Amgen, Astra Zeneca, Abbvie, Boehringer Ingelheim, Celgene, Janssen Cilag, Leo Pharma, Novartis, and Pfizer, and has received speaker honoraria from Abbvie, Janssen Cilag, and Novartis.

\section{References}

[1] Griffiths CE, Barker JN. Pathogenesis and clinical features of psoriasis. Lancet 2007;370:263-71

[2] Augustin M, Glaeske G, Radtke MA, et al. Epidemiology and comorbidity of psoriasis in children. Br J Dermatol 2010;162:633-6.

[3] Mehta NN, Yu Y, Pinnelas R, et al. Attributable risk estimate of severe psoriasis on major cardiovascular events. Am J Med 2011;124:e1-6.

[4] Boehncke WH, Boehncke S, Tobin AM, et al. The 'psoriatic march': a concept of how severe psoriasis may drive cardiovascular comorbidity. Exp Dermato 2011:20:303-7.

[5] Gerdes S, Rostami-Yazdi M, Mrowietz U. Adipokines and psoriasis. Exp Dermatol 2011;20:81-7.

[6] Guerre-Millo M. Adipose tissue and adipokines: for better or worse. Diabetes Metab 2004;30:13-9.

[7] Johnston A, Arnadottir S, Gudjonsson JE, et al. Obesity in psoriasis: leptin and resistin as mediators of cutaneous inflammation. Br J Dermatol 2008;159:342-50. 
[8] Otero M, Lago R, Lago F, et al. Leptin, from fat to inflammation: old questions and new insights. FEBS Lett 2005;579:295-301.

[9] Hamminga EA, van der Lely AJ, Neumann HAM, et al. Chronic inflammation in psoriasis and obesity: Implications for therapy. Med Hypotheses 2006;67:768-73.

[10] Cerman AA, Bozkurt S, Sav A, et al. Serum leptin levels, skin leptin and leptin receptor expression in psoriasis. Br J Dermatol 2008;159:820-6.

[11] Augustin M, Radtke MA, Glaeske G, et al. Epidemiology and comorbidity in children with psoriasis and atopic eczema. Dermatology 2015;231:35-40.

[12] Koebnick C, Black MH, Smith N, et al. The association of psoriasis and elevated blood lipids in overweight and obese children. J Pediatr 2011;159:577-83.

[13] Jensen P, Zachariae C, Iversen L, et al. Cardiovascular risk factors in children and adolescents with psoriasis: a case-control study. Acta Derm Venereol 2014;94:76-8.

[14] Paller AS, Mercy K, Kwasny MJ, et al. Association of pediatric psoriasis severity with excess and central adiposity: an international cross-sectional study. JAMA Dermatol 2013;149:166-76.

[15] Osier E, Wang AS, Tollefson MM, et al. Pediatric psoriasis comorbidity screening guidelines. JAMA Dermatol 2017:153:698-704.

[16] Boccardi D, Menni S, La Vecchia C, et al. Overweight childhood psoriasis. Br J Dermatol 2009;161:484-6.

[17] De Jager ME, de Jong EM, Meeuwis KA, et al. No evidence found that childhood onset of psoriasis influences disease severity, future body mass index or type of treatments used. J Eur Acad Dermatol Venereol 2010;24:1333-9.

[18] Bryld LE, Sørensen TI, Andersen KK, et al. High body mass index in adolescent girls precedes psoriasis hospitalization. Acta Derm Venereol 2010;90:488-93.

[19] Zhu KJ, He SM, Zhang C, et al. Relationship of the body mass index and childhood psoriasis in a Chinese Han population: a hospital-based study. J Dermatol 2012;39:181-3.

[20] Mahé E, Maccari F, Beauchet A, et al. Childhood onset psoriasis: association with future cardiovascular and metabolic comorbidities. Br J Dermatol 2013;169:889-95.

[21] Goldminz AM, Buzney CD, Kim N, et al. Prevalence of the metabolic syndrome in children with psoriatic disease. Pediatr Dermatol 2013;30:700-5.

[22] Volf EM, Levine DE, Michelon MA, et al. Assessor-blinded study of the metabolic syndrome and surrogate markers of increased cardiovascular risk in children with moderate-to-severe psoriasis compared with age-matched population of children with warts. J Drugs Dermatol 2011;10:900-1.

[23] Au SC, Goldminz AM, Loo DS, et al. Association between pediatric psoriasis and the metabolic syndrome. J Am Acad Dermatol 2012;66:1012-3.

[24] Becker L, Tom WL, Eshagh K, et al. Excess adiposity preceding pediatric psoriasis. JAMA Dermatol 2014;150:573-4.

[25] Torres T, Machado S, Mendonça D, et al. Cardiovascular comorbidities in childhood psoriasis. Eur J Dermatol 2014:24:229-35.

[26] Mahé E, Beauchet A, Bodemer C, et al. Psoriasis and obesity in French children: a case-control, multicentre study. Br J Dermatol 2015;172:1593-600.

[27] Lee A, Smith SD, Hong E, et al. Association between pediatric psoriasis and waist-to-height ratio in the absence of obesity: A multicenter Australian study. JAMA Dermatol 2016;152:1314-9.

[28] Tom WL, Playford MP, Admani S, et al. Characterization of lipoprotein composition and function in pediatric psoriasis reveals a more atherogenic profile. J Invest Dermatol 2016;136:67-73.

[29] Cole TJ, Bellizzi MC, Flegal KM. Establishing a standard definition for child overweight and obesity worldwide: international survey. BMJ 2000;320: $1240-1243$.
[30] McCrindle BW, Urbina EM, Dennison BA, et al. Drug therapy of high-risk lipid abnormalities in children and adolescents: a scientific statement from the American Heart Association Atherosclerosis, Hypertension, and Obesity in Youth Committee. Council of cardiovascular disease in the youth, with the council on cardiovascular nursing. Circulation 2007;115:1948-67.

[31] Daniels SR, Greer FR. The committee on nutrition. Lipid screening and cardiovascular health in childhood. Pediatrics 2008;122:198-208.

[32] Lambert D, Daubrosse E, Steinmetz J, et al. Valeurs de référence du cholestérol et des triacylglycérols plasmatiques et lipoprotéiniques chez des enfants sains. Arch Fr Pédiatr 1987;41:145-50.

[33] Siest G, Visvikis S, Herbeth B, et al. Objectives, design and recruitment of familial and longitudinal cohort for studying gene-environment interactions in the field of cardiovascular risk: the Stanislas cohort. Clin Chem Lab Med 1998;36:35-42.

[34] Mellerio-Lagrange H. A novel modelling of references values for the components of the metabolic syndrome in children aged 7 to 20 years. Paris VII: Université Denis Diderot; 2009.

[35] National High Blood Pressure Education Program Working Group on High Blood Pressure in Children and Adolescents. The fourth report on the diagnosis, evaluation, and treatment of high blood pressure in children and adolescents. Pediatrics 2004;114(Suppl 4th Report):555-76.

[36] Expert Panel on Detection, Evaluation, Treatment of High Blood Cholesterol in Adults. Executive summary of the Third Report of the National Cholesterol Education Program (NCEP) Expert Panel on Detection, Evaluation, and Treatment of High Blood Cholesterol in Adults (Adult Treatment Panel III). JAMA 2001;285:2486-97.

[37] Balkau B, Charles MA. Comment on the provisional report from the WHO consultation. European Group for the Study of Insulin Resistance (EGIR). Diabetes Med 1999;16:442-3.

[38] Alberti KG, Zimmet P. Shaw J. Metabolic syndrome: a new worldwide definition. A consensus statement from the International Diabetes Federation. Diabetes Med 2006;23:469-80.

[39] Reaven GM. Banting lecture 1988. Role of insulin resistance in human disease. Diabetes 1988:37:1595-607.

[40] Alberti KGMM, Zimmet PZ, World Health Organization Consultation. Definition, diagnosis and classification of diabetes mellitus and its complications, part 1: diagnosis and classification of diabetes mellitus. Provisional report of a WHO consultation. Diabetes Med 1998;15:539-53.

[41] Grundy SM, Brewer Jr HB, Cleeman JI, et al. Definition of metabolic syndrome: report of the National Heart, Lung and Blood Institute/American Heart Association conference on scientific issues related to definition. Arterioscler Thromb Vasc Biol 2004;24:e13-8.

[42] Mimoun E, Aggoun Y, Pousset M, et al. Association of arterial stiffness and endothelial dysfunction with metabolic syndrome in obese children. J Pediatr 2008; 153:65-70.

[43] Pietrzak A, Grywalska E, Walankiewicz M, et al. Psoriasis and metabolic syndrome in children: current data. Clin Exp Dermatol 2017;42:131-6.

[44] Mahé E. Childhood psoriasis. Eur J Dermatol 2016;26:537-48.

[45] Mahé E, Reguiai Z, Barthelemy H, et al. Evaluation of risk factors for body weight increment in psoriatic patients on infliximab: a multicentre, crosssectional study. J Eur Acad Dermatol Venereol 2014;28:151-9.

[46] Preventive Services Task Force US, Bibbins-Domingo K, Grossman DC, et al. Screening for lipid disorders in children and adolescents: US preventive services task force recommendation statement. JAMA 2016;316: 625-633. 